Отже, оволодіння майбутніми вчителями-словесниками письменницької ключової компетентності сприяє творчому становленню індивідуума; дозволяе гіпотетично відновити мистецьку лабораторію письменника, що підвищує якість вивчення курсу історії української літератури; відповідно ефективність професійної діяльності випускника вищої школи. На часі розроблення методистами науково обгрунтованої системи формування професійно-творчих здібностей студентів-гуманітаріїв.

\title{
Література
}

1. Гринберг Б. Обучение сочинению-рассуждению на литературную тему как методическая проблема / Б. Гринберг // Проблемы филологического образования : [матер. VII зональной научн.-практ. конфер. «Актуальные проблемы филологического образования: наука-вуз-школа»]. - Екатеринбург : Изд-во АМБ, 2001. - С. 20-23.

2. Зимняя И. Ключевые компетентности - новая парадигми результата образования / И. Зимняя // Высшее образование сегодня. - 2003. - №5. - С. 3-7.

3. Йогансен М. Вибрані твори / Майк Йогансен. - К. : Смолоскип, 2001. - 516 с.

4. Кузнецов Ю. Навчити думати... Ще раз про мету освіти у профільній школі / Юрій Кузнецов // Українська мова й література в середніх школах, гімназіях, ліцеях та колегіумах. - 2007. - №1. - С.4-10.

5. Логвіненко Н. Література мрії i передбачення. Вивчення української фантастичної прози в системі факультативних занять / Н. Логвіненко // Українська література в загальноосвітній школі. - 2009. - №12. - С. 25-28.

6. Токмань Г. Методика викладання української літератури в старшій школі: екзистенціально-діалогічна концепція / Г. Токмань. - К. : Міленіум, 2002. - 320 с.

7. Українська література. 5-12 класи: програма для загальноосвітніх навчальних закладів / за заг. ред. Мовчан Р. В. - К. : Перун, 2005. - 201 с.

8. Фурсова Л. Від літературної компетенції - до життєвої компетентності / Людмила Фурсова // Українська мова й література в середніх школах, гімназіях, ліцеях та колегіумах. - 2005. - №5. - С.12-21.

Стаття надійшла до редакції 12.05.2012 p.

УДК 371.134:371.381

Л. О. Савченко, кандидат пед. наук, доиент, Криворізький педагогічни інститут ДВНЗ «Криворізький начіональний університет»

\section{КОМПЕТЕНТНІСНИЙ КОНЦЕПТ ФОРМУВАННЯ ЯКОСТІ ПІДГОТОВКИ МАЙБУТНІХ УЧИТЕЛІВ} учителів.

Савченко Л. О.Компетентнісний концепт формування якості підготовки майбутніх

У статті розкрито концептуальне тлумачення комптентнісного підходу $і$ специфіки його застосування під час викладання педагогічних дисциплін у вищий школі. Комптентнісний підхід визначається професійними базовими знаннями та вміннями, ціннісними орієнтаціями, мотивами діяльності викладача, розумінням себе і довкілля, стилем взаємин з людьми, загальною культурою, здатністю до розвитку свого творчого потенціалу.

Ключові слова: компетентність, компетенція, компетентнісний підхід. учителей.

Савченко Л. А. Компетентносный конщепт формирования качества подготовки будущих

В статье раскрыты кониептуальное толкование комптентносного подхода и специфики его применения при преподавании педагогических дисциплин в высший школе. Комптентносный 
подход определяется профессиональными базовыми знаниями и умениями, иенностными ориентачиями, мотивами деятельности преподавателя, пониманием себя и окружающего мира, стилем взаимоотношений с людьми, общей культурой, способностью к развитию своего творческого потенциала.

Ключевые слова: компетентность, компетенция, комптентносный подход.

Savchenko L. Kompetentnosny concept of formation of the quality of future teachers.

In article conceptual interpretation of a komptentnosny approach and specifics of its application are opened when teaching pedagogical disciplines in the highest to school. The Komptentnosny approach decides by professional basic knowledge and abilities, valuable orientations, motives of activity of the teacher, understanding of and world around, style of relationship on people, the general culture, ability to development of the creative potential.

Key words: competence, competence, komptentnosny approach.

Постановка проблеми. Якість освіти $є$ поліструктурною єдністю компонентів, характеристика яких відображає процес та результат досягнення діагностично заданої мети освітнього процесу. Основним компонентом якості освіти $є$ компетентностний підхід.

Розглядаючи компетентнісний підхід, важливо розібратися у трактуванні самих понять «компетенція» і «компетентність». Нині наявні два основних варіанти витлумачення співвідношення цих понять:

1) ототожнення понять «компетенція» і «компетентність». Згідно з цим варіантом найбільш грунтовно й переконливо поданому у Глосарії термінів Європейського фонду освіти (1997), компетенція визначається як:

- здатність робити щось добре чи ефективно;

- відповідність вимогам, що висуваються під час влаштування на роботу;

- здатність виконувати особливі трудові функції.

2) диференціація понять «компетенція» і «компетентність». Ми поділяємо позицію І.Зимньої, яка розмежовує поняття «компетенція» i «компетентність». Орієнтоване на компетенції освіта формувалося в 1970-х роках в Америці в загальному контексті запропонованого Н. Хомський у 1965 році (Массачусетський університет) поняття «компетенція» стосовно до теорії мови, трансформаційній граматиці.

Отже, у 60-х роках XX століття вже було закладено розуміння розглянутих нині відмінностей між поняттями «компетенція» $\mathrm{i}$ «компетентність», де останнє трактується як те, що грунтується на знаннях, інтелектуально і особистісно зумовлена соціально-професійна життєдіяльність людини. При цьому зауважимо, що самі поняття «компетенція», «компетентність» і похідне «компетентний» широко використовувалися i раніше - в побуті, літературі, його тлумачення наводилося в словниках.

Так, наприклад, у словнику іноземних слів наводиться таке визначення: «компетентний (лат. competens, competentis належний, здібний):

a) той, хто знає, розуміється на певній галузі;

б) має право відповідно до своїх знань або повноважень робити чи вирішувати що-небудь, судити про що-небудь»[4]. 
Заснований на компетенції підхід, перш за все, підкреслює практичний, дієвий складник. Тоді як підхід, заснований на понятті «компетентність», яке містить власне особистісні (мотивація, якісні, мотиваційно-вольові та інші) якості, визначається як більш широкий, що співвідноситься i 3 гуманістичними цінностями освіти. Загальна феноменологія педагогічної (професійно-педагогічної, психологопедагогічної) компетентності та ії особистих видів знайшла відображення у великій кількості вітчизняних та зарубіжних досліджень. У сучасній науці проблема педагогічної компетентності не має однозначного розв'язання. Концептуальне тлумачення цього поняття i специфіка області його застосування задають різний зміст і розуміння цього феномену.

Останні публікації 3 теми дослідження. Ряд науковців (Л. Анциферова, Ю. Варданян, І. Колесникова, І. Климкович, Н. Кузьміна, Н. Матяш, А. Маркова, С. Огарев, С. Павлюченков та інші) визначають зміст професійної компетентності, виявляючи психологічні, педагогічні, соціальні умови ¥ї становлення. Вони розглядають іiі:

- як сукупність професійних якостей (Л. Анциферова);

- як складну одиничну систему внутрішніх психічних станів i властивостей особистості спеціаліста, готовність до здійснення професійної діяльності та здатність виконувати необхідні для цього дії (Ю. Варданян);

- як здатність реалізовувати на певному рівні професійно-посадові вимоги (І. Климкович);

- як професійну самоосвіту (А. Маркова);

- як стійку здатність до діяльності зі «знанням справи» (В. Огарев);

- як здатність до актуального виконання діяльності (М. Чошанов) тощо.

Неоднозначно дослідники розуміють і структурні компоненти професійної компетентності. Так, одні автори мають на увазі ієрархію знань та умінь (А. Казакова, Л. Комаровська, Н. Кузьміна), інші (Ю. Варданян, А. Маркова, Н. Матяш, С. Павлюченков) - сукупність специфічних здібностей, що передбачають професійну майстерність. Інша група авторів (Н. Кузьміна, В. Сластьонін, Є. Рогов та інші) розглядають педагогічну компетентність як найбільш стійкі якості особистості. Вони вважають, що розвиток індивіда в діяльності, спілкуванні забезпечують більш якісний підхід до професійних завдань.

В. Сластьонін визначає педагогічну компетентність через поняття:

- педагогічної рефлексії;

- емоційної стійкості;

- врахування індивідуальних особливостей, нахилів, характера педагога;

- позитивного відношення до праці [3].

Є. Рогов розглядає педагогічну компетентність як «професіоналізм педагога». У це поняття він вкладає такі сукупні характеристики, які відображають психофізіологічні, психічні і особистісні зміни, які відбуваються в роботі вчителя в самому процесі оволодіння тривалого виконання діяльності, що забезпечує якісно новий, ефективніший рівень розв'язання складних професійних задач в особливих умовах. 
Мета статті. Розкрити концептуальне тлумачення розглядуваного поняття і специфіки його застосування у процесі викладання у вищий школі.

Отримані результати. Професійна компетентність спеціаліста - це складна єдина система внутрішніх психічних станів i властивостей особистості: готовності до професійної діяльності та здатності виробляти необхідні для цього дії. Ця система не піддається прямому спостереженню, а виявляється опосередковано в процесі і внаслідок професійної діяльності.

Професійна компетентність педагога - явище багатогранне, що визначається професійними базовими знаннями та вміннями, ціннісними орієнтаціями, мотивами діяльності викладача, розумінням себе і навколишнього світу, стилем взаємин із людьми, загальною культурою, здатністю до розвитку свого творчого потенціалу.

У зарубіжних дослідженнях розроблюється модель «компетентності працівника», де упор робиться на ту частину спектру індивідуальнопсихологічних якостей, в яку входять самостійність, дисциплінованість, комунікативність, потреба в саморозвитку [2]. Так, американський психолог К. Доуле вважає важливим компонентом кваліфікації здатність швидко та безконфліктно адаптуватися до конкретних умов праці. Інший американський психолог Е. Шорт характеризує кваліфікаційного працівника як людину, яка володіє знаннями основ наук та уміннями, з ними пов'язаними, а також навиками, необхідними для виконання психомоторних функцій, професійних ролей, когнітивної і афективної діяльності, міжособистісного спілкування. При цьому звертається увага на розвиток здібностей, знань, умінь, мотивів, відношень, переконань, цінностей, необхідних для компетентного виконання соціальних ролей і взаємодії зі світом. На думку Р. Лібсона, компетентний викладач має володіти такими знаннями й уміннями: знати зміст предмета, що викладається; вміти застосовувати психологічні принципи, до яких відносяться:

- знання з вікової психології та уміння їх застосувати;

- уміння адекватно реагувати на дії учнів, батьків, колег;

- уміння адаптуватися до нових ситуацій та інновацій.

Загалом науковці відносять компетентність до загальної характеристики індивіда i не пов'язують іiі 3 розрізненими уміннями. В основі західноєвропейських моделей компетентності покладено такі якості, як уміння самостійно знаходити шляхи розв'язання комплексних завдань, оволодіння новими знаннями, навиками, позитивне уявлення про свою особистість, здатність гармонійного спілкування, уміння поводитися в колективі. У руслі концепції професійного розвитку вчителя поняття «педагогічна компетентність» включає, на думку Л. Мітіної, знання, уміння, навики, а також засоби та прийоми їх реалізації в діяльності, спілкуванні, розвитку (саморозвитку) особистості. Або, іншими словами, під педагогічною компетентністю Л. Мітіна розуміє гармонійне поєднання знання предмета, методики й дидактики викладання, умінь і навиків (культури) педагогічного спілкування, а також прийомів і засобів саморозвитку, самовдосконалення, самореалізації [2]. 
У роботі ми намагалися впровадити різні ситуації, задачі, які б підвищили рівень компетентності майбутніх вчителів. Наприклад, упровадження до навчального процесу тренінгових вправ. Вправа 1. Ознайомтесь зі змістом педагогічної ситуації. Спробуйте виявити проблему. Подумайте і доберіть декілька ситуацій такого ж типу. Проаналізуйте, чи правильно ви зрозуміли сутність вихідної ситуації. Вправа 2. За умовами педагогічної задачі спробуйте самостійно визначити діагностичну мету, оберіть засоби, адекватні вихідним даним. Аргументуйте свій вибір.

Задачі з несформульованим питанням. У задачах цієї серії питання не формулюється, але воно логічно слідує із даних в задачі числових відношень. Визначається, чи може досліджуваний сформулювати питання, чи розуміє він сенс даних в задачі відношень і залежностей, чи сприймає він вказівки викладача. Ця серія спрямована на виявлення сприйняття навчально-пізнавальних задач і наявних в них особливостей студентами. Ця серія дозволяє з'ясувати, як сприймає студент задачу, яка його готовність до процесу рішення, тобто чи бачить він в ній лише сукупність не пов'язаних даних або сприймає іiі у комплексі взаємозалежних величин. У першому випадку має місце не повністю спостерігаємий процес, в другому «ступінь неопосередкованого спостереження» буде близька до одиниці. Ця серія задач складається 3 трьох тестів, які пропонуються один за одним. Отримавши задачу, учень має прочитати іiі i за можливості швидше сформулювати питання. При цьому фіксується увесь хід роздумів досліджуваного, припущені при цьому помилки і вид корекційного впливу, необхідного для зменшення їх кількості.

Задачі з неповним складом даних. Тут відсутні деякі дані, внаслідок чого дати точну відповідь на питання задачі неможливо. Встановлюється, чи може досліджуваний знайти комплекс відносин заданих величин, необхідних для рішення задачі, і вказати на невистачаючі дані. Ця серія, як і попередня, спрямована на виявлення деяких особливостей пізнавальних дій учнів (сприйняття та осмислення), на знаходження перехідних станів процесу учіння, тих його структурних ланок, на які повинно бути направлений педагогічний вплив.

Смисл задач цієї серії полягає в тому, що вказати на відсутні дані може тільки студент, який сприймає формальну структуру задачі і систему взаємопов'язаних величин, що складають ï сутність.

Серія складається 3 двох тестів, які пропонуються один за одним. Отримавши картку з задачею, студент відразу спостерігає, що не можна дати точну відповідь на питання задачі, або робить цей же висновок після роздумів. У цьому і в другому випадку йому ставляться питання: «Чому не можна дати точну відповідь на питання задачі?», «Чого не вистачає?», «Що необхідно додати?». Студентам, які перебувають на більш високому пізнавальному рівні, ставляться такі питання: «Чи можна що-небудь одержати із наявних даних?», «Який висновок можна зробити 3 аналізу поданого?» 
У всіх випадках фіксується хід роздумів, кількість виконаних задач, відсоткове відношення помилок, час виконання, кількість i форма корекційних впливів, кількість дій, які випали.

Посилання студентів на неможливість точного рішення без пояснення $\mathrm{i}$ мотивації, без визначення відсутніх даних, розцінюється як неправильна відповідь.

Задачі з надлишком інформащії. У подібні задачі введено додаткові показники, які не мають значення і маскують необхідні для рішення дані. Встановлюються можливості вибіркової здатності розумового процесу. Інакше кажучи, ця серія задач дозволяє визначити, як студенти із сукупності даних їм величин виокремлюють ті, які визначають сутність задачі, $\epsilon$ необхідними і достатніми для її розв'язання.

Тести, що складають зміст серії, подаються один за одним. У дослідженні студентів 3 високим рівнем пізнавальних дій застосовувався прийом, який полягав у тому, що задачі другої та третьої серії давалися змішаними. Це виключало настанову на те, що в одній групі задач «чогось не вистачає», а в другій - «щось зайве».

Отримавши картку 3 задачею, досліджуваний має виокремити мінімальну кількість даних, необхідних для рішення, і пояснити, чому в інших немає потреби. Фіксується хід міркувань, кількість виконаних задач, час виконання, типи корекційних дій.

Задачі з взаємопроникаючими елементами. Ця серія спрямована на дослідження деяких особливостей декомпозиційного сприйняття виучуваних явищ, які відбуваються в різних системах та їх елементах, а саме, уміння розглядати та оцінювати «взаємопроникаючі» (термін І. Якіманської) процеси, виділити їх параметри і характеристики із фона, бачити один і той же процес (параметр) у різних структурах і давати йому відповідну інтерпретацію.

При цьому фіксується повнота відповіді, роль «образу» процесу i логіка розмірковувань, керованість розумовим процесом, його адаптованість при неповному інформаційному забезпеченні. Попередньо студенту пояснюється характер завдання на конкретному прикладі.

Система однотипних задач. Експеримент має початковий характер. Досліджується процес узагальнення - підведення об'єктів під тільки-но сформований у своїй основі поняття, процес переносу способу дій, здатність диференціювати зовнішньо однотипний матеріал за істотною ознакою. Для цього необхідно виокремити головне з позиції типу задач, відволіктися від неістотного, другорядного. Ступінь навченості і здатність до узагальнення визначається по тому, наскільки студент вміє бачити загальний тип в різних задачах, переходити від рішення простих до більш складних задач того ж типу, як вміє їх диференціювати. Про здатність мислити «згорнутими» категоріями судять, аналізуючи процес роздумів і систему відповідних пізнавальних дій при послідовному рішення однотипних задач.

Утворення штучних зв'язків $i$ понять. Завдання цієї серії мають за мету виявити специфіку здатності студентів до узагальнення і готовність до 
самостійної професійної діяльності. Тести представляють собою модифікацію методики виникнення штучних понять, розробленої Л. Виготським. Тести відрізняються один від одного за рівнем складності, кожен з них пропонують студентові у вигляді карток з малюнками. Ці малюнки характеризуються формою, насиченістю і кольором. Частина цих малюнків об'єднується у штучне поняття за двома 3 трьох даних ознак. Відповідно, в кожному тесті одні ознаки є суттєвими, а інші - несуттєвими. Студенту дають завдання відібрати всі картки із зображенням малюнків, які відносяться до даного поняття, намагаючись обійтися якомога меншою кількістю проб. Фіксується, як досліджуваний розмірковує при цьому, за допомогою яких умовиводів приходить до рішення задачі, як виокремлює істотні ознаки, як абстрагується від несуттєвих, як узагальнює і як у нього фіксується поняття. Кількісний показник - число проб, тобто кількість карток, які обере студент, перш ніж відбере всі картки, що характеризують поняття, і назве його характерні ознаки [5].

Евристичні завдання. Про навченість, здібності та готовність до професійної діяльності слід судити не за тим, що студенти знають і якими навиками володіють, а за тим, як легко і швидко, яким шляхом вони здобули відповідні знання, уміння і навички. Завдання цієї серії розраховані на дослідження того, як студент оволодіває новим для нього матеріалом, як евристично відкриває невідомі закономірності, установлює функціональні залежності, виконує узагальнення.

Такі завдання $є$ оптимальним індикатором професійних здібностей, так як вимагають тільки елементарних знань. Задачі такого типу розкривають механізми внутрішніх інформаційних процесів, вони показують, як студент може думати, логічно виводи одне 3 іншого. Аналіз процесу роздумів може допомогти зрозуміти деякі моменти, пов'язані, наприклад, з виникненням «позитивного» зворотного зв'язку, здогадок, що виникають у студентів під час розмірковування.

Висновки. Наголошуючи на тому, що компетенції - це деякі внутрішні, потенційні, приховані психологічні новоутворення (знання, уявлення, програми, алгоритми дій, системи цінностей і відносин), які потім виявляються в компетентності людини як актуальних, діяльнісних виявах. I. Зимня позначила коло цих основних компетенцій, маючи на увазі їх подальші вияви як компетентностей. Усього виокремлено десять основних компетенцій.

Отже, можна зробити такі висновки.

По-перше, дослідники виокремлюють діяльнісну, актуальну сутність компетентності, підкреслюючи, що на відміну від знаннєвої характеристики, тобто характеристики «що», у компетентності акцентується, підкреслюється саме спосіб і характер дії «як».

По-друге, більшість дослідників виокремлюють особистісну, зокрема, мотиваційну характеристику компетентності. 
По-третє, фіксують складний характер цього соціально-педагогічного явища, як у його визначенні, так і у використанні й оцінюванні результатів. Подальшу свою роботу ми вбачаємо в розробленні завдань із педагогічної практики, яка сприятиме підвищенню професійної компетентності майбутнього вчителя.

\title{
Література
}

1. Митина Л. М. Психология профессионального развития учителя / Лариса Максимовна Митина. - М. : Московский психолого-социальный институт; Издательство «Флинта», 1998. - $180 \mathrm{c}$.

2. Равен Дж. Компетентность в современном обществе: выявление, развитие и реализация / Дж. Равен. - М. : Когито-Центр, 2002. - 257c.

3. Сластенин В. А. Профессионализм педагога: акмеологический контекст /В. А. Сластенин // Педагогическое образование и наука. - 2002. - №4. - С. 1-9.

4. Словарь иностранных слов / под ред. И.В. Лехина, С.М. Локшиной и др.; [изд. 6-е]. - М. : Советская энциклопедия, 1964. - 784 с.

5. Шаталов А. А. Мониторинг и диагностика качества образования: [монография]/ Шаталов А. А., Афанасьев В. В., Афанасьева И. В., Гвоздева Е. А., Пичугина А. М. - М. : НИИ школьных технологий, 2008. - 322 с.

Стаття надійшла до редакції 23.05.2012 p.

УДК. 37.043 .048

Н. В. Берестецька, кандидат пед.наук, доцент, Начіональна академія Державної прикордонної служби України імені Богдана Хмельнииького

\section{НОВІ ПІДХОДИ ДО ОРГАНІЗАЦІЇ САМОСТІЙНОЇ ПІДГОТОВКИ ПЕРСОНАЛУ ДЕРЖАВНОЇ ПРИКОРДОННОЇ СЛУЖБИ УКРАЇНИ}

\begin{abstract}
Берестецька Н. В. Нові підходи до організащії самостійної підготовки персоналу Державної прикордонної служби Украӥни.

На трунті проведеного теоретичного аналізу наукових джерел та нормативних документів проаналізовано організацію самостійної підготовки персоналу Державної прикордонної служби України, вивчено нові підходи до ї̈ ефективного використання в підрозділах охорони кордону, а також запропоновано методичні рекомендації щодо ї̈ вдосконалення. Особливу увагу приділено вивченню іноземної мови персоналом ДПСУ під час самостійної підготовки та розроблення індивідуальних завдань для прикордонників.

Ключові слова: самостійна підготовка, персонал, Державна прикордонна служба України, індивідуальне завдання.

Берестечкая Н. В. Новые подходы к организации самостоятельной подготовки персонала Государственной пограничной службы Украины.

На основе проведенного теоретического анализа научных источников и нормативных документов проанализировано организаиию самостоятельной подготовки персонала Государственной пограничной службы Украины, изучено новые подходы к ее эффективному использованию в подразделениях охраны гранищы, а также предложены методические рекомендации $\kappa$ ее улучшению. Особое внимание уделено изучению иностранного языка персоналом ГПСУ во время самостоятельной подготовки та разработке индивидуальных заданий для пограничников.
\end{abstract}

Ключевые слова: самостоятельная подготовка, персонал, Государственная пограничная служба Украины, индивидуальные задания. 